Boerhaave hay Hội chứng võ̃ thực quản do nôn ói mạnh tại bệnh viển Chợ Rẫy và Bệnh viện cấp cứu Trưng Vương trong 14 năm (1999-2012)". Tạp chí Y học Thành phố Hồ Chí Minh, 17, tr. 44-52.

4. Huu Vinh V., Viet Dang Quang N., Van Khoi N. (2019) "Surgical management of esophageal perforation: role of primary closure". Asian Cardiovasc Thorac Ann, 27 (3), tr. 192-198.

5. Chirica Mircea, Kelly Michael D., Siboni Stefano, Aiolfi Alberto, Riva Carlo Galdino, Asti Emanuelevà cộng sự (2019) "Esophageal emergencies: WSES guidelines". World Journal of Emergency Surgery, 14 (1), tr. 26.

6. Dickinson Karen Joanna, Blackmon Shanda $H$. (2015) "Endoscopic Techniques for the Management of Esophageal Perforation". Operative Techniques in Thoracic and Cardiovascular Surgery, 20 (3), tr. 251-278.

7. Soreide J. A., Viste A. (2011) "Esophageal perforation: diagnostic work-up and clinical decision-making in the first 24 hours". Scand J Trauma Resusc Emerg Med, 19, tr. 66

8. Hasimoto C. N., Cataneo C., Eldib R., Thomazi R., Pereira R. S., Minossi J. G.và cộng sự (2013) "Efficacy of surgical versus conservative treatment in esophageal perforation: a systematic review of case series studies". Acta Cir Bras, 28 (4), tr. 266-71.

9. Misiak P., Jablonski S., Piskorz L., Dorozala L., Terlecki A., Wcislo S. (2017) "Oesophageal perforation - therapeutic and diagnostics challenge. Retrospective, single-center case report analysis (2009-2015)". Pol Przegl Chir, 89 (4), tr. 1-4.

10. White C. S., Templeton P. A., Attar S. (1993) "Esophageal perforation: CT findings". AJR Am J Roentgenol, 160 (4), tr. 767-70.

11. Brinster C. J., Singhal S., Lee L., Marshall M. B., Kaiser L. R., Kucharczuk J. C. (2004) "Evolving options in the management of esophageal perforation". Ann Thorac Surg, 77 (4), tr. 1475-83.

12. Attar S., Hankins J. R., Suter C. M., Coughlin T. R., Sequeira A., McLaughlin J. S. (1990) "Esophageal perforation: a therapeutic challenge". Ann Thorac Surg, 50 (1), tr. 45-9; discussion 50-1.

13. Young C. A., Menias C. O., Bhalla S., Prasad S. R. (2008) "CT features of esophageal emergencies". Radiographics, 28 (6), tr. 1541-53.

14. Mavroudis Constantine $D$., Kucharczuk John C. (2013) "Acute Management of Esophageal Perforation". Current Surgery Reports, 2 (1), tr. 34.

15. Sdralis E. I. K., Petousis S., Rashid F., Lorenzi B., Charalabopoulos A. (2017) "Epidemiology, diagnosis, and management of esophageal perforations: systematic review". Dis Esophagus, 30 (8), tr. 1-6.

16. Wright C. D., Mathisen D. J., Wain J. C., Moncure A. C., Hilgenberg A. D., Grillo H. C. (1995) "Reinforced primary repair of thoracic esophageal perforation". Ann Thorac Surg, 60 (2), tr. 245-8; discussion 248-9.

17. Blasberg Justin D., Wright Cameron D. (2015) "Management of Esophageal Perforation". Adult Chest Surgery. 2nd ed. McGraw-Hill,

\title{
THỰC TRẠNG KIẾN THỨC THỰC HÀNH VỀ TUÂN THỦ ĐIỀU TRI CỦA NGƯờI BỆNH TĂNG HUYẾT ÁP VÀ MộT SỐ YẾU TỐ LIÊN QUAN TẠI BỆNH VIÊ̂N BACCH MAI
}

\section{TÓM TẮT}

Nghiên cứu mô tả cắt ngang kết hợp phân tích thực hiên trên 384 bênh nhân tai Khoa Khám bênh, Bệnh viện Bạch Mai từ tháng 12/2020 đến tháng 5/2021 trên bệnh nhân tăng huyết áp đến khám bệnh tai bệnh viên Bach Mai. Mục tiêu phân tích tuân thủ điều trị, chằm sóc người bệnh tăng huyết áp và một số yếu tố liên quan. Có đạt kiến thức chung về tăng huyết áp là $68 \%$ và chưa đạt về kiến thức chiếm $32 \%$. Thực hành chung về điều trị tăng huyết áp mức đạt là $40,9 \%$ và chưa đạt là $59,1 \%$; Về tuân thủ thực hành điêu trị tăng huyết áp tốt chiếm $63,5 \%$ và tuân thủ chưa tốt chiếm 36,5\%; Có sự khác biệt rõ rệt và

\section{${ }^{1}$ Bệnh viện Bach Mai}

${ }^{2}$ Trường $\oplus H$ Thăng Long

Chịu trách nhiệm chính: Nguyễn Thị Hường

Email: huongnguyebvbm@gmail.com

Ngày nhận bài: 26.10.2021

Ngày phản biên khoa hoc: 23.12.2021

Ngày duyệt bài: 30.12.2021

\section{Nguyễn Thị Hường1, Lê Thị Bình ${ }^{2}$}

có ý nghĩa thống kê giữa tuổi > 60 tuổi và $<60$ tuổi với tuân thủ điều trị $(p<0,05)$, giữa $B M I<18,5$ và $18,5-23(p<0,05)$, giữa BMI < 18,5 và > 23 ( $p<$ $0,05)$, giữa thời gian bị THA mắc bệnh trên 10 năm và dưới 10 năm với tuân thủ điêu trị $(p<0,000)$. Giữa đã từng có biến chứng và không với tuân thủ điêu trị ( $p$ $<0,000)$. Giữa có tăng Lipid máu với tuân thủ điêu tri $(p<0,000)$. Giữa kiến thức chưa đạt và có kiến thức đat với tuân thủ điều trị $(p<0,000)$; giữa nhóm BMI với kiến thức; giữa thời gian bị bệnh $<5$ năm và $>5$ năm với kiến thức $(p<0,05)$; giữa đã từng bi biến chứng với thực hành $(p<0,05)$. Giữa Kiến thức về tăng huyết áp đạt và chưa đạt với thực hành đạt và chưa đạt $(p<0,000)$

Keywords: Treatment adherence, knowledge, practice, care, counseling for patients

\section{SUMMARY \\ CURRENT STATUS OF KNOWLEDGE AND \\ PRACTICE ON TREATMENT ADHERENCE OF HYPERTENSIVE PATIENTS AND SOME RELATED FACTORS AT BACH MAI HOSPITAL}


A cross-sectional descriptive study combined with analysis was performed on 384 patients at the Department of Examination, Bach Mai Hospital from December 2020 to May 2021 on hypertensive patients visiting Bach Mai hospital. Objectives Analyze treatment adherence, care for hypertensive patients and some related factors. Having general knowledge about hypertension is $68 \%$ and not having knowledge about $32 \%$. General practice on hypertension treatment reached $40.9 \%$ and not reached $59.1 \%$; Regarding adherence to good hypertension treatment practice, $63.5 \%$ and poor adherence accounted for $36.5 \%$; There is a significant and statistically significant difference between age $>60$ years old and $<60$ years old with treatment adherence $(p<0.05)$ between BMI < 18.5 and $18.5-23(p<0,05)$, between BMI $<18.5$ and $>23(p<0.05)$, between duration of hypertension over 10 years and less than 10 years with adherence $(p<0.000)$. Between ever had complications and no adherence $(p<0.000)$. Between hyperlipidemia and adherence $(p<0.000)$. Between unsatisfactory knowledge and pass knowledge with treatment adherence $(p<0,000)$; between BMI group and knowledge; between disease duration $<5$ years and $>5$ years with knowledge $(p<$ 0.05); between ever having complications with practice ( $p<0.05)$. Between passing and failing knowledge of hypertension and passing and failing practice $(p<0.000)$

\section{I. ĐĂTT VẤN ĐỀ}

Tăng huyết áp (THA) là bệnh thường gặp, là một trong những bệnh âm thẩm mạn tính có thể gây tử vong nghiêm trọng nếu khổng được chă sát. Theo báo cáo của hội Tim Mạch học Việt Nam, tính đến tháng 5 nằm 2016 tỷ lệ THA là $47,3 \%$, trong đó chỉ có $31,3 \%$ THA kiểm soát được [3].Hiện nay tăng huyết áp (THA) gia tăng trên toàn thế giới và được mệnh danh là "kẻ giết người thầm lặng". Tăng huyết áp liên quan đến $69 \%$ nhồi máu cơ tim lân đâu, $74 \%$ các ca bênh động mạch vành, $77 \%$ đột quy não lần đâu và $91 \%$ các ca suy tim [4]. Với tính chất của bệnh cần phải theo dõi huyết áp và dùng thuốc hạ áp suốt đời, do đó dễ dàng nhận thấy việc người bệnh phải tuân thủ dùng thuốc là vô cùng cần thiết. Rất nhiều nguyên nhân làm giảm sự tuân thủ trong sử dụng thuốc trên bênh nhân tăng huyết áp, nhưng nguyên nhân cớ bản được chỉ ra là người bệnh hoàn toàn thụ động và chỉ quan tâm khi thấy ảnh hưởng tới sức khỏe bản thân [5]. Đây thực sự là một thách thức đối với ngành y tế nói chung và điều dưỡng trực tiếp theo dõi chăm sóc nói riêng. Nhiệm vụ chăm sóc, tư vân cho người bệnh đòi hỏi phải kiên nhẫn giúp người bênh tuân thủ điều tri bằng cách tư vấn kiến thức, thực hành về tuân thủ điêu trị cho người bệnh. Từ thực tễ trên đề tài Thực trạng kiến thức, thực hành về tuân thủ điều trị của người bênh tăng huyết áp và một số yếu tố liên quan tại Bệnh viện Bạch Mai năm 2020 - 2021" được tiến hành nhằm muc tiêu sau: Phân tích tuẩn thủ điều trị của người bệnh và một số yếu tố liên quan.

\section{II. ĐỐl TƯỢNG VÀ PHƯƠNG PHÁP NGHIÊN CỨU}

1. Đối tượng nghiên cứu: Tiêu chuẩn lựa chọn: Người bệnh được chẩn đoán THA đang điều trị ngoại trú tại Khoa Khám Bệnh - Bệnh viện Bạch Mai. Thời gian: 12/2020 đến 5/2021

2. Thiết kế nghiên cứu: Nghiên cứu mô tả cắt ngang

3. Cỡ mẫu: 384 bệnh nhân tăng huyết áp tại Khoa Khám Bệnh - Bệnh viện Bạch Mai.

4. Biến số NC: Tuổi, giới, nghề nghiệp, trình độ học vấn, thời gian mắc bệnh, kiến thức tuân thủ, thực hành tuân thủ, chăm sóc tư vấn cho người bệnh,...

5. Xử lý số liệu: phân tích, xử lý bằng phân mềm SPSS 20.0 để tính tỷ lệ phần trăm, phân tích đơn biến các yếu tố liên quan đến chưa tuân thủ điều trị, khác biệt có ý nghĩa thống kê khi $p<0,05$.

\section{KẾT QUẢ NGHIÊN CứU}

\section{Thực trạng tuân thủ điêu trị của người bệnh tăng huyết áp}

Bảng 1. Thực trạng tuân thủ điều trị của người bệnh tăng huyêt áp

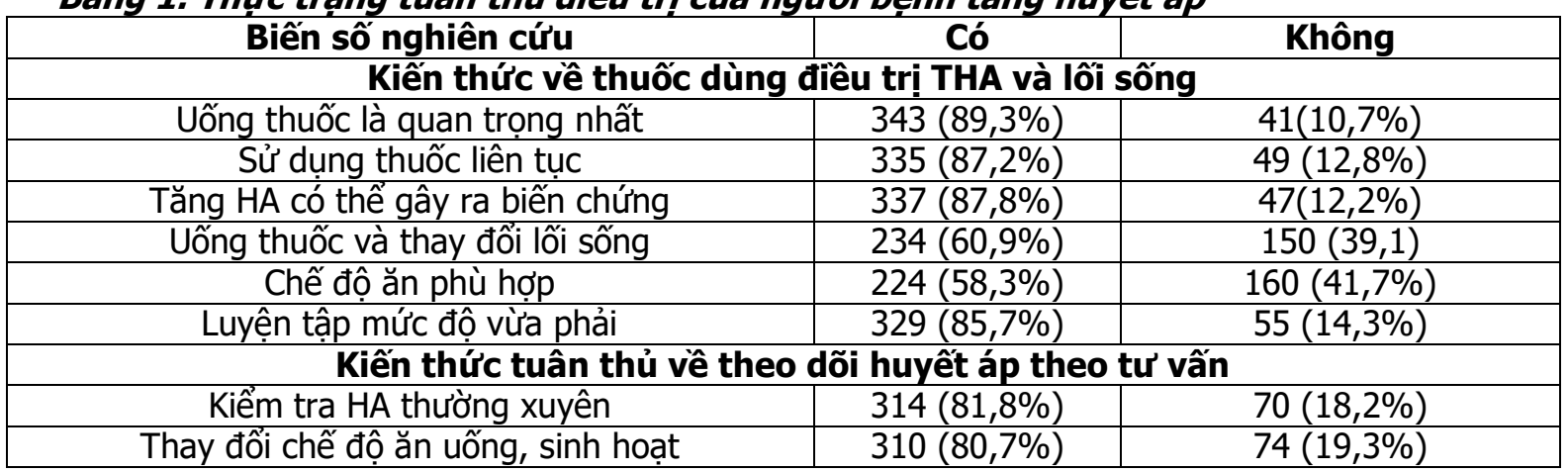




\begin{tabular}{|c|c|c|}
\hline Biết trị số xác định THA & $280(72,9 \%)$ & $104(27,1 \%)$ \\
\hline Theo dõi sức khỏe định kỳ tái khám & $306(79,7 \%)$ & $78(20,3 \%)$ \\
\hline Cách theo dõi HA hợp lý & $251(65,4 \%)$ & $133(34,6 \%)$ \\
\hline \multicolumn{3}{|c|}{ Đánh giá chung về kiến thức về bênh tăng huyết áp } \\
\hline Đạt kiến thức về bệnh & 261 & 68,0 \\
\hline Chưa đạt kiến thức về bệnh & 123 & 32,0 \\
\hline \multicolumn{3}{|c|}{ 2. Thực hành tuân thủ điêuu trị của người bệnh tăng THA } \\
\hline \multicolumn{3}{|c|}{ Thực hành tuân thủ trong khám sức khỏe định kỳ } \\
\hline 01 tháng/lần & 180 & 46,9 \\
\hline 03 tháng/lần hoặc Khi nào ốm mới đi khám & 204 & 53,1 \\
\hline \multicolumn{3}{|c|}{ Thực hành tuân thủ về đo huyết áp (tần suất đo) } \\
\hline Hàng ngày & 219 & 57,0 \\
\hline Đo khi chóng mặt, đau đầu, khi vào viện,... & 165 & 43,0 \\
\hline \multicolumn{3}{|l|}{ Sở thích hút thuốc lá, lào } \\
\hline Hiện tại vấn hút thuốc lá, lào & 21 & 5,4 \\
\hline Đã từng hút và hiện không hút & 363 & 94,6 \\
\hline $\begin{array}{l}\text { Tuân thủ trong sở thích ăn chất béo: } \\
\text { Dùng dầu ăn hoàn toàn }\end{array}$ & 116 & 30,2 \\
\hline Có ăn mõ̃ động vật nhưng ăn ít & 268 & 69,8 \\
\hline \multicolumn{3}{|c|}{ Đánh giá chung về thực hành tuân thủ điêuu trị của người bệnh } \\
\hline Tuân thủ thực hành & 157 & 40,9 \\
\hline Chưa tuân thủ thực hàn & 227 & 59,1 \\
\hline
\end{tabular}

Kiến thức tuân thủ dùng thuốc điêu trị tăng huyết áp và thay đổi lối sống: có kiến thức về uống thuốc là điều quan trong nhất để kiểm soát huyết áp chiếm 89,3\%; Hiểu khi bị THA phải sử dụng thuốc liên tục 89,3\%; biết không điều trị tốt THA sẽ gây ra biến chứng nguy hiểm chiếm $87,8 \%$; hiểu là chỉ cần uống thuốc và thay đổi lối sống chiếm $60.9 \%$; chế độ ăn phù hợp $58,3 \%$; luyện tập mức độ vừa phải $85,7 \%$.

Kiến thức tuân thủ theo dõi bệnh huyết áp theo tư vấn: Có kiến thức tuân thủ kiểm tra huyết áp thường xuyên chiếm $81,8 \%$; có kiến thức tuân thủ về thay đổi chế độ ăn uống, sinh hoat giúp kiểm soát HA chiếm $80,7 \%$; ckiến thức hiểu biết trị số xác định tăng huyết áp chiếm $72,9 \%$; biết TD sức khỏe định kỳ tuân thủ tái khám theo hẹn chiếm $79,7 \%$; cách theo dõi HA hợp lý chiếm $65,4 \%$. Đánh giá chung về kiễn thức tuân thủ điều trị: Có kiến thức tuân thủ (68\%), không (32\%)

Thực hành tuân thủ: Thực hành tuân thủ trong khám sức khỏe định kỳ 1 tháng/lần chiếm 46,9\%. Và 03 tháng/lần hoăc Khi nào ốm mới đi khám là $53,1 \%$; Về tuân thủ về đo huyết áp (tần suất đo) là $57 \%$ và chỉ thực hiện đo $\mathrm{HA}$ khi chóng mặt, đau đầu, khi vào viện,...chiếm $43 \%$. Về sở thích hút thuốc lá, lào: hiên tại NB vẫn nghiện không bỏ được chiếm 5,4\%; NB đã đã từng hút và hiện không hút chiếm $94,6 \%$. Về sở thích ăn chất béo: Dùng dầu ăn hoàn toàn $(30,2 \%)$ và NB có ăn ít mõ̃ động vật $(69,8 \%)$.

Đánh giá chung về thực hành tuân thủ: có tuân thủ thực hành là $40,9 \%$ và chưa tuân thủ thực hành chiếm $59,1 \%$.

3. Một số yếu tố liên quan đến tuân thủ điêu trị ở người bệnh tăng huyết áp

3.1. Liên quan giữa đặc điểm chung của đối tượng nghiên cứu với tuân thủ điều trị

Bảng 2. Sự liên quan giữa đặc điểm của đôi tượng nghiên cứu với tuân thủ điều trị

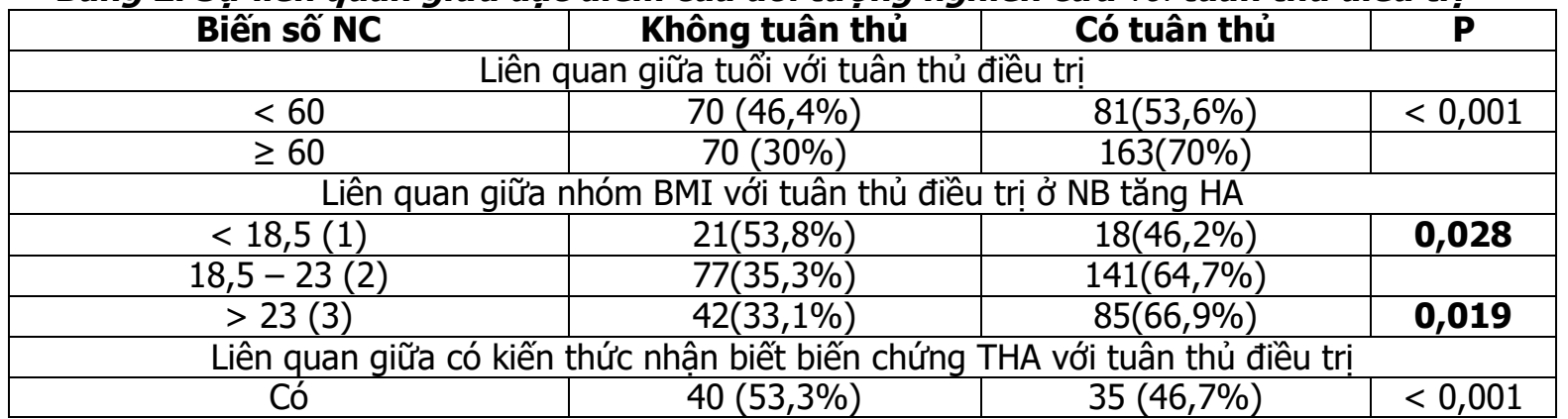




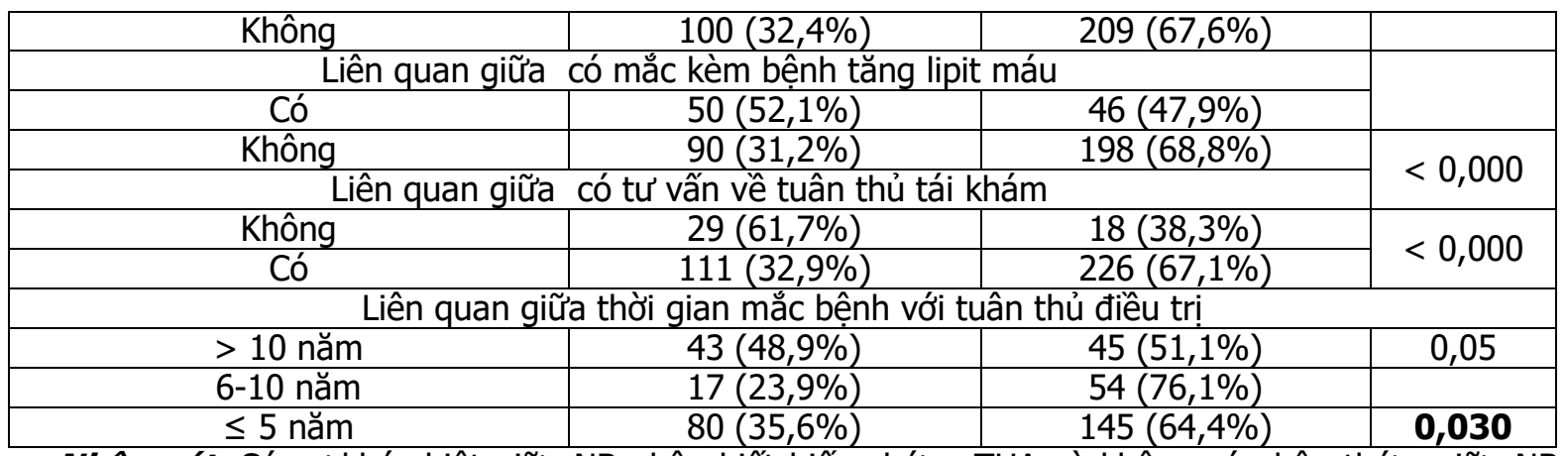

Nhận xét: Có sự khác biệt giữa NB nhận biết biến chứng THA và không có nhận thức; giữa NB giữa có mắc kèm bệnh tăng lipit máu và không mắc; giữa NB có tuân thủ tái khám và không tuân thủ với tuân thủ điêu trị $(p<0,000)$. Liên quan giữa NB có thời gian mắc bệnh $>10$ năm và thời gian mắc từ $6-10$ năm với tuân thủ điều trị $(p<0,05)$; giữa có thời gian mắc bệnh $>10$ năm và $\leq 5$ năm với tuân thủ điêu trị $(p<0,030)$.

Bảng 3. Liên quan giữa kiến thức, thực hành với tuân thủ điều trị

Biến số nghiên cứu $\quad$ Không tuân thủ $\quad$ Có tuân thư

\begin{tabular}{|c|c|c|c|}
\hline Biến số nghiên cứu & Không tuân thủ & Có tuân thủ & $\mathbf{P}$ \\
\hline \multicolumn{4}{|c|}{ Liên quan giữa kiến thức về bệnh THA với tuân thủ điều trị } \\
\hline Chưa đạt & $56(45,5 \%)$ & $67(54,5 \%)$ & $<0,010$ \\
\hline Đạt & $84(32,2 \%)$ & $177(67,8 \%)$ & \\
\hline \multicolumn{4}{|c|}{ Liên quan giữa thực hành với tuân thủ điều trị } \\
\hline Chưa đạt & $105(85,4 \%)$ & $18(14,6 \%)$ & $<0,000$ \\
\hline Đạt & $122(46,7 \%)$ & $139(53,3 \%)$ & \\
\hline
\end{tabular}

Nhận xét: có sự liên quan rõ rệt giữa kiến thức chưa đạt và NB có kiến thức đạt về bệnh THA với tuân thủ điều trị $(p<0,010)$. Có sự liên quan rõ rệt giữa thực hành chưa đạt và có thực hành đạt với tuân thủ điêu trị $(\mathrm{p}<0,000)$

Bảng 4. Liên quan giữa hoạt động chăm sóc, tư vấn với tuân thủ điều trị

\begin{tabular}{|l|l|l} 
Biến số nghiên cứu & Không tuân thủ & Có tuân thủ
\end{tabular}

Liên quan giữa chăm sóc tâm lý với tuân thủ điều trị

\begin{tabular}{c|c|c|c|}
\cline { 1 - 3 } Không & $27(60,0 \%)$ & $18(40,0 \%)$ & \multirow{2}{*}{0,000} \\
\cline { 1 - 3 } & $113(33,3 \%)$ & $226(66,7 \%)$ & \\
\hline
\end{tabular}

Liên quan giữa hoạt động tư vấn dinh dưỡng, tư vấn về tái khám định kỳ với tuân thủ điều trị

\begin{tabular}{|c|c|c|c|}
\hline Không & $29(61,7 \%)$ & $18(38,3 \%)$ & 0,000 \\
\hline Có & $111(32,9 \%)$ & $226(67,1 \%)$ & \\
\hline
\end{tabular}

Nhận xét: có liên quan rõ rệt giữa chưa có thực hiện chăm sóc tâm lý và người bệnh được chăm sóc tâm lý với tuân thủ điều trị $(p<0,000)$. Liên quan giữa người bệnh không được tư vấn về dinh dưỡng, về tái khám và người bệnh có được tư vấn với tuân thủ điều trị $(p<0,000)$.

\section{BÀN LUẬN}

1. Kiến thức tuân thủ điêu trị của người bệnh (NB) tăng huyết áp

NB có kiến thức về bệnh: Nhận thức được là có dấu hiệu báo trước khi bị THA $(78,4 \%)$; có hiểu biết bệnh THA có nguy hiểm $(85,2 \%)$; biết về THA có thể chữa ổn định $(65,9 \%)$; biết về bệnh HA có thể kiểm soát được $(86,7 \%)$. KQNC của chúng tôi cao hơn Đỗ Thị Hiến (72,5\%) [4].

Về kiến thức tuân thủ dùng thuốc điều trị tăng huyết áp và thay đổi lối sống: $K Q$ của chúng tôi có kiến thức về uống thuốc chiếm 89,3\%; Hiểu khi bị THA phải sử dụng thuốc liên tục 89,3\%; biết không điêu trị tốt THA sẽ gây ra biến chứng nguy hiểm chiếm $87,8 \%$; Hiểu là chỉ cần uống thuốc và thay đổi lối sống chiếm 60.9\%; Chễ độ ăn phù hợp 58,3\%; Luyện tập mức độ vừa phải $85,7 \%$. Kết quả của chúng tôi người bệnh có kiến thức Ngô Thị Hương Giang, của Phạm Thị Hồng Vân [2],[8].

Kiển thức tuân thư theo dõi bệnh huyết áp theo tư vấn: Có kiến thức tuân thủ kiểm tra huyết áp thường xuyên chiếm $81,8 \%$; Có kiến thức tuân thủ về thay đổi chế độ ăn uống, sinh hoạt giúp kiểm soát HA chiếm $80,7 \%$, kết quả này này cao hơn gấp 2 lần so với kết quả của Phamm Thị Hồng Vân là 37,2\%[8]. Về kiến thức hiếu biết trị số xác định tăng huyết áp chiếm 72,9\%; cách theo dõi HA hợp lý chiếm 65,4\%; biết theo dõi sức khỏe định kỳ tuân thủ tái khám 
theo hẹn chiếm $79,7 \%$, kết quả này của chúng tôi thấp hơn so với Ngô Vương Hoàng Giang có tỷ lệ tái khám theo hẹn chiếm 98,6\%[3]. Đánh giá chung về kiến thức tuân thủ điêu trị: Có kiến thức tuân thủ (68\%), không (32\%) kết quả này của chúng tôi cao hơn của Đố Thị Hiến (có tuân thủ là $64,75 \%$ và không tuân thủ là 35,25\%)[4]

\section{Về thực hành tuân thủ điêu trị:}

Thực hành tuân thủ: Thực hành tuân thủ trong khám sức khỏe định kỳ 1 tháng/lần chiếm $46,9 \%$ và 03 tháng/lần hoặc khi nào ốm mới đi khám là $53,1 \%$; Về tuân thủ về đo huyết áp (tần suất đo) là $57 \%$ và chỉ thực hiện đo $\mathrm{HA}$ khi chóng mặt, đau đầu, khi vào viện,...chiếm $43 \%$. Về sở thích hút thuốc lá: hiện tại NB vẫn nghiện không bỏ được chiếm 5,4\%; NB đã đã từng hút và hiên không hút chiếm $94,6 \%$. Về sở thích ăn chất béo: dùng dầu ăn hoàn toàn $(30,2 \%)$ và NB có ăn ít mõ động vật $(69,8 \%)$. KQNC của chúng tôi cao hơn KQNC của Đố Thi Hiến có thực hành tuân thủ về sử dụng thuốc chiếm $31 \%$, mức trung bình chiếm $33 \%$ và tuân thủ kém cũng chiếm 35,25\% [4]. Đánh giá chung về tuân thủ thực hành: có tuân thủ thực hành là $40,9 \%$ và chưa tuân thủ thực hành chiếm $59,1 \%$. Nhưng kết quả tuân thủ thực hành của chúng tôi lại thấp hơn rất nhiều so với của Phạm Thị Hồng Vân năm 2020 có kết quả tuân thủ thực hành chiếm khá cao từ gần $90 \%$ đến $96,1 \%$; chưa tuân thủ thực hành chỉ chiếm 3,9\%[ 8].

3. Một số yếu tố liên quan đến tuân thủ điều trị của NB tăng HA

3.1. Liên quan giữa đăc điểm chung của đối tượng nghiên cứu với tuân thủ điều trị

Về tuổi: Có sự liên quan giữa $>60$ tuổi và từ 50-60 tuổi với tuân thủ điều trị $(p<0,05)$; có sự liên quan giữa $>60$ tuổi và $<50$ tuối với tuân thủ điều trị $(p<0,05)$. KQNC của chúng tôi cũng phù hợp với kết quả nghiên của Đố Thị Hiến năm 2020 [4] và của Phạm Thị Hồng Vân năm 2020 cũng có sự khác biệt và có ý nghĩa thống kê ( $p$ < $0,05)[8]$.

Liên quan giữa nhóm $\mathrm{BMI}<18,5$ và $18,5-$ $23(\mathrm{p}<0,028 ; \mathrm{OR}(1 / 2)=2,14)$; giữa < 18,5 và $>23(\mathrm{p}<0,019 ; \mathrm{OR}(1 / 3)=2,36)$ với tuân thủ điều trị $(p<0,000)$, kết quả này cũng tương đồng nghiên cứu Phạm Thị Hồng Vân năm 2020 $(p<0,05)$ [8]. Có sự khác biệt giữa NB nhận biết biến chứng THA và không có nhận thức với tuân thủ điều trị $(p<0,05)$ kết quả này tương đồng với Ngô Thị Hương Giang 2013 ( $p<0,05$ ) [2] nhưng lai trái ngược với nghiên cứu của Phạm Thị Hồng Vân là chưa tìm thây sự khác biệt $(p>0,05)$ có lẽ do nghiên cứu của Phạm
Thị Hồng Vân là có cỡ mẫu nhỏ chưa đủ lớn mạnh để tìm thấy sự khác biệt [8]; giữa NB có mẳc kèm bệnh tăng lipid máu và không mắc, nghiên cứu của chúng tôi có trái ngược với kết quả của Nguyễn Thị Kim Dung năm 2017 khi bị bệnh huyết áp có mắc kèm bị bệnh thận, bệnh tiểu hóa, tăng lipid máu, mắc kèm bệnh lý hô hấp là chưa tìm thấy sự khác biệt (đều có $p$ > $0,05)[1]$; giữa NB có tuân thủ tái khám và không tuân thủ với tuân thủ điều trị $(p<0,000)$ điều này có thể giải thích rằng khi NB được tư vấn về tầm quan trong của việc tái khám thì dù nhiều hay ít nội dung tư vấn cũng có hiệu quả cho người bệnh, nếu họ không được tư vấn, sẽ không có thông tin, kiến thức để tuân thủ theo cũng là đương nhiên. Liên quan giữa NB có thời gian mắc bệnh > 10 năm và thời gian mắc từ 6 10 năm với tuân thủ điều trị $(p<0,05)$; giữa có thời gian mắc bệnh $>10$ năm và $\leq 5$ năm với tuân thủ điêu trị $(p<0,030))$ kết quả này tương đồng với Ngô Thị Hương Giang $2013(p<0,05)$ [2] và Ngô Vương Hoàng Giang 2020 tại An Giang $(p<0,05)[3]$

Liên quan giữa kiến thức, thực hành với tuân thủ điêu trị: Có sự liên quan rõ rệt giữa kiến thức chưa đạt và NB có kiến thức đạt về bệnh THA với tuân thủ điều trị $(p<0,010)$. Có sự liên quan rõ rệt giữa thực hành chưa đạt và có thực hành đạt với tuân thủ điêu trị $(p<$ $0,000)$. Kết quả này cũng tương đồng với kết quả của Đỗ Thị Hiến cũng có kiến thức chung tuân thủ điều trị bệnh tăng huyết áp có sự khác biệt có ý nghĩa thống kê giữa 2 nhóm NB tăng HA "có tuân thủ điều trị" và "không tuân thủ điêu trị" với $p<0,05$ [4]. KQNC của chúng tôi cho thấy, có sự liên quan rõ rệt giữa thực hành chưa đạt và có thực hành đạt với tuân thủ điêuu trị $(p<0,000)$. Kết quả này cũng tương đồng với kết quả của Nguyễn Thị Mai và CS năm 2019 tại một số tỉnh phía Bắc $(p<0,05)[5]$

Mối liên quan giữa hoạt động chăm sóc của điêu dưỡng với tuân thủ điêuu trị THA: Bảng 6 cho thấy, có sự khác biệt rõ rệt và có ý nghĩa thốngkê giữa NB có được chăm sóc về tâm lý (động viên an ủi, trấn an tinh thần, đáp ứng nhu cầu thiết yếu, an tâm và giảm lo lắng về bệnh,...) và chưa được chăm sóc tâm lý ( $p$ < 000). Có sự liên quan và có ý nghĩa thống kê giữa NB có được tư vấn, giáo dục sức khỏe với nội dung sự cần thiết về dinh dưỡng khi bị tăng huyết áp và $N B$ không được tư vấn với $p<$ 0,001 . Có sự khác biệt rõ rệt và có ý nghĩa thông kê giữa NB có được tư vấn, giáo dục sức khỏe về tầm quancủa việc tái khám định kỳ khi mắc 
bệnh tăng huyết áp và NB không được tư vấn với $p<0,000$. Có thể giải thích rằng khi $N B$ đến khám và điều trị ngay từ đầu đã được điều dưỡng giao tiếp rất tận tình được NB hài lòng chiếm $71,4 \%$, kết quả của chúng tôi phù hợp với NC của Bùi Minh Thông nhu cầu cần được chăm sóc của NB chiếm $91,4 \%$, cần được tư vấn sức khỏe rất lớn chiếm tới 80,9\%[7]. Có sư liên quan giữa NB chưa được tư vấn, tốt và NB được tư vấn tốt với tuân thủ điều trị $(p<0,007)$.

\section{KẾT LUÂN}

- Tuân thủ điêu trị của người bênh: về kiến thức: Có kiến thức tuân thủ $(68 \%)$, không (32\%) Về thực hành: có tuân thủ thực hành là $40,9 \%$ và chưa tuân thủ thực hành chiểm $59,1 \%$.

- Một số yếu tố liên quan: Có sự liên quan giữa $\geq 60$ tuổi và $<60$ tuổi với tuân thủ điều trị ( $p<0,05)$; Có sự liên quan giữa nghề nghiệp; giữa nhận biết biến chứng THA; giữa NB mắc kèm bệnh tăng lipit máu; giữa thời gian mắc bệnh > 10 năm và từ $6-10$ năm, giữa kiến thức chưa đạt và NB có kiến thức đạt; giữa thực hành chưa đạt và có thực hành đạt; giữa chưa có thực hiện CS tâm lý và NB được CS tâm lý; giữa không được tư vấn về dinh dưỡng, về tái khám và NB có được tư vấn với tuân thủ điều trị $(p<0,05)$.

\section{TÀI LIÊU THAM KHẢO}

1. Nguyễn Thị Kim Dung và CS (2020), Khảo sát tình trang tăng huyết áp của người bênh ở những ngày đâuu sau ghép thận. Tạp chí Y Dược lâm sàng 108, tập 15, số đặc biệt, tháng 11/2020, tr 142-148
2. Ngô Thị Hương Giang (2013), Kiến thức, thực hành và một số yếu tố liên quan đến phòng biến chứng ở người bi tăng huyết áp tai huyên Thanh Trì, Hà Nội, 2013, Luận văn thạc sỹ, Trường Đại hoc Y tế Công Công.

3. Ngô Vương Hoàng Giang (2020) Thực trạng tuân thủ điêu trị của bệnh nhân tăng huyết áp điều tri ngoại trú tại Khoa Khám bênh, Trung tâm Y tế Huyện Thoại Sơn, An Giang., Tạp chí Y học thức hành, Tâp 31 , số 62021

4. Đố Thị Hiến và CS (2020), Đánh giá sự tuân thủ điều trị ở bệnh nhân tang huyết áp được điều trị ngoai trú tai Phòng khám Nôi Tim mach - Bênh viện Trung ương Quân đội 108, Tap chí Y Dược lâm sàng 108, Hội nghị khoa học điểu dưỡng bệnh viện 2020, tập 15, 11/2020

5. Nguyến Thị Mai và CS (2019), Kiến thức về tăng huyết áp và đái tháo đường của bác sĩ đa khoa công tác tại Trạm Y tế xã ở một số tỉnh miền Bắc., Tạp chí Y học Việt Nam, Tập 4911, tháng 6, số 1, nắm 2020, Trang 64-69.

6. Nguyê̂n Hồng Mînh và CS (2018), Mô tả nhu cầu của người bệnh đến kham tại Khoa Khám bệnh, bệnh viện Trung ương Quân đội 108, quý 1 năm 2018. Tap chí Y Dược lâm sàng 108, Hội nghị khoa học điều dưỡng 2018, tập 13, số đặc biệt 8/2018, trang $300-307$.

7. Bùi Mính Thông và CS (2018), Thực trạng công tác giáo duc sức khỏe cho người bềnh tai bênh viện Nội tiết trung ương năm 2018. . Kỷ yếu Hội nghị khoa học bệnh viện Nội Tiết trung ương mở rông năm 2019. Tir $349-35 \dot{5}$.

8. Phạm Thị Hông Vân và CS (2020), Tìm hiểu kiến thức và thưc hành tuân thủ điều tri của bênh nhân tăng huyểt áp tai Viện Điều trị Cán bộ cao cấp Quân đội. Tap chí Y Dược lâm sàng 108, Hội nghi khoa học điểu dưỡng bệnh viện 2020, tập 15, sổ đặc biệt 11/2020

\section{KHẢO SÁT Ý KIẾN CỦA NGƯờI BÊNNH ĐỐI VỚI HÊ THỐNG ĐĂNG KÝ KHÁM BỆNH NGOẠI TRÚ TRỰC TUYẾN TẠI KHOA KHÁM BỆNH BÊ̂NH VIỆN ĐẠI HỌC Y DƯợC TP.HCM}

\section{TÓM TẮT}

Đă̆t vấn đề: Hiên nay tại Việt Nam người bệnh (NB) chủ yếu vẫn sử dụng hình thức đăng ký khám bệnh truyền thống, việc này làm tiêu tốn khá nhiều thời gian và nhân lực cho việc nhận đăng ký, đồng thời không nhận được sự hài lòng cao từ NB và người

${ }^{1}$ Bệnh viện Đại học Y dược TP. Hồ Chí Minh

${ }^{2}$ Trường Đại học Y tế công cộng

Chiu trách nhiệm chính: Thái Hoài Nam

Email: nam.th@umc.edu.vn

Ngày nhân bài: 22.10.2021

Ngày phản biện khoa học: 20.12.2021

Ngày duyệt bài: 27.12.2021

\section{Thái Hoài Nam¹, Hoàng Văn Minh²}

nhà NB. Nhiều nghiên cứu trước đây đã cho thấy rằng lợi ích từ việc đăng kí khám bệnh trực tuyến là vượt trôi hơn so với hình thức đăng ký truyền thống. Do đó việc triển khai áp dụng hê̂ thống đăng ký khám bệnh ngoai trú trực tuyến và tiến hành đánh giá phản hồi của NB tại Khoa khám bệnh tại Bệnh viện là điều vô cùng cần thiết. Muc tiêu: Khảo sát ý kiến của người bệnh đối với hệ thống đăng ký khám bệnh ngoại trú trực tuyến tại k̉hoa khám bênh Bệnh viện Đại học $Y$ Dược TP.HCM. Đối tượng và phương pháp nghiên cứu: Nghiên cứu cắt ngang mô tả, định lượng kết hợp định tính, được tiến hành trên 672 người bệnh từ 18 đển 74 tuổi đến khám ngoại trú tại Khoa khám bệnh thuộc Cơ sở 1- Bệnh viên Đai học Y Dược TP. Hồ Chí Minh trong thời gian từ tháng 1 đến tháng 3/2020. Kết quả: Khoảng 95\% người bệnh hài lòng khi đăng 